\title{
NEUROPEPTIDES
}

\section{Expression of Prodynorphin-derived Peptides and mRNA in Guinea-pig Cortex}

\author{
C. D. RAMSDELL and J. H. MEADOR-WOODRUFF
}

Mental Health Research Institute, Department of Psychiatry, University of Michigan, 205 Zina Pitcher Place, Ann Arbor, MI 48109-0720, USA (Reprint requests to JHMW)

\begin{abstract}
The distributions and extent of processing of four prodynorphin-derived peptides (dynorphin A (1-17), dynorphin A (1-8), dynorphin B, and $\alpha$-neoendorphin) were determined in ten regions of the cortex as well as in the striatum of the guinea-pig. There were significant differences between concentrations of these peptides in most cortical regions, with $\alpha-$ neoendorphin being several times more abundant than the other peptides, and dynorphin $A$ (1-17) being present in the least amount. There were significant between-region differences in concentration for each peptide, although most regions had concentrations similar to those seen in the striatum. Concentrations of each peptide tended to be higher in piriform, entorhinal, motor, and auditory cortex than in other cortical regions. The extent of processing of prodynorphin varied across cortical regions as well, primarily due to the extent of processing to $\alpha$-neoendorphin. Prodynorphin mRNA levels were not significantly different between cortical regions or from the amount observed in the striatum. Although specific regional variation exists, it appears that in general prodynorphin is expressed and processed in a similar manner in the cortex as in the striatum.
\end{abstract}

\section{Introduction}

The endogenous opioid peptides are produced by post-translational processing of one of three propeptides, proenkephalin, pro-opiomelanocortin, or prodynorphin (prodyn). Each of these precursor molecules can undergo tissue-specific post-translational processing to produce distinct mixes of active peptide products, which are often unique for given

Date received 3 March 1993

Date accepted 3 March 1993

Correspondence to: Dr. James H. Meador-Woodruff, Mental Health Research Institute, Department of Psychiatry, University of Michigan, 205 Zina Pitcher Place, Ann Arbor, MI 48109-0720, USA brain regions. ${ }^{1}$ Proenkephalin can be processed to the opioid active enkephalins, and pro-opiomelanocortin to a number of functional peptides including $\beta$-endorphin. Prodyn contains three major functional domains which can produce a variety of active ligands (Fig. 1). The neoendorphin (NE) domain consists of $\alpha-\mathrm{NE}$, which can be further processed to $\beta-N E$. The dynorphin (dyn) A domain, which is dyn $A$ (1-17), can be further processed to dyn A (1-8). The dyn B domain (leumorphin) can be processed to dyn $B$. All three of these domains contain leucine enkephalin, which is a theoretical final processing product.

The endogenous opioid ligands have varying 


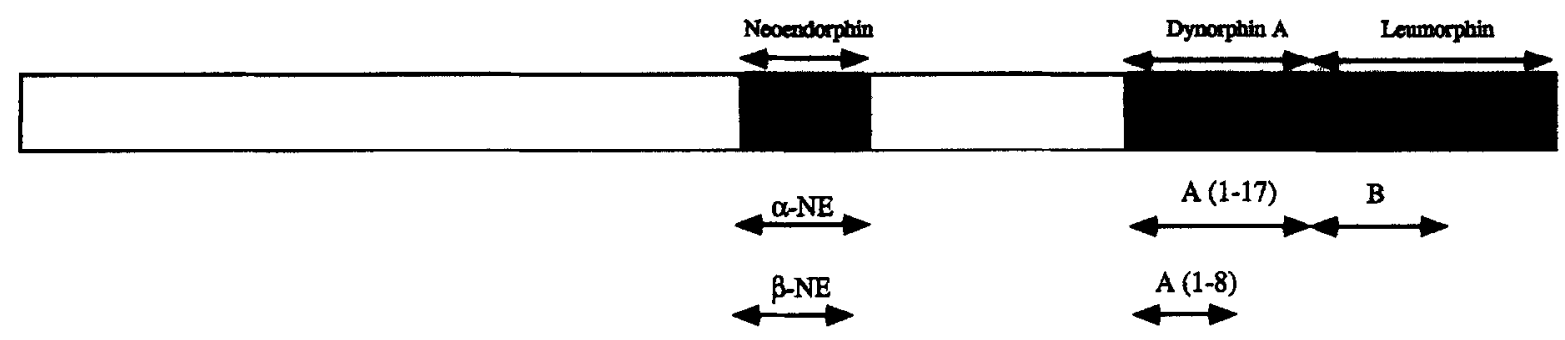

Fig. 1 Schematic of prodynorphin molecule. The major opioid-active domains of prodyn are shown. $\alpha$-neoendorphin can be further processed to $\beta$-neoendorphin, dynorphin A (1-17) to dynorphin A (1-8), and leumorphin to dynorphin B.

affinities for the different subtypes of opioid receptors. ${ }^{2,3}$ Proenkephalin and pro-opiomelanocortin both produce peptide products that have activity at the $\mu$ and $\delta$ receptors. Prodyn, however, is a particularly rich precursor molecule: in addition to producing ligands active at the $\mu$ and $\delta$ sites, this propeptide can also produce peptides with relatively high affinities for the $\mathrm{\kappa}$ receptor. For example, dyn $A(1-17)$, dyn $B$, and $\alpha-\mathrm{NE}$ are all active at the $\kappa$ receptor, having affinities for the $\kappa$ receptor about 5 times higher than for the $\mu$ receptor, and about 20 times higher than for the $\delta$ receptor. Compared with dyn A (1-17), however, dyn A (1-8) has a relatively higher affinity for the $\delta$ receptor. Thus, the extent of processing of the dyn A domain partially determines the relative $\delta \mathrm{vs} \kappa$ functional activity of this domain of prodyn. The combination of abundance and extent of processing of prodyn in any given brain region thus contributes to the specific overall opioid tone in that region.

Prodyn as well as $\kappa$ receptors are fairly widespread in the mammalian brain. ${ }^{2,4,5,6} 13$ The striatum, substantia nigra, hippocampus, amygdala, and hypothalamus are particularly enriched in these molecules. The characterization of brain prodyn has concentrated on deep brain structures; the nigrostriatal system has been particularly well-characterized. ${ }^{14-16}$ The striatum contains numerous prodynsynthesizing cells, which project to the substantia nigra. In this system in the rat, relatively high levels of prodyn are found, and the dyn A domain is found primarily expressed as dyn A(1-8)

The cortex of most species has also been demonstrated to contain relatively high levels of both $\mathrm{K}$ receptor binding as well as prodyn-containing neurons. ${ }^{17,18}$ While the nigrostriatal system has been fairly well-characterized, however, little is known concerning the prodyn found in the cortex. Although past studies have shown that prodyn-derived products as well as mRNA can be found in much of the cortex, a systematic study of the extent of distribution and processing of dyn has not been reported. Does the cortex handle prodyn in a manner similar to the nigrostriatal system, or is either the synthesis or post-translational processing different? Is prodyn distributed and processed the same in all of cortex, or do certain regions express and/or process this propeptide uniquely? The purpose of the current study was to determine the distribution of prodyn mRNA and peptides, as well as the extent of posttranslational processing, in multiple cortical regions of the rodent, and to compare these data with that found in the striatum. We have selected the guineapig for this study, as this animal has been reported to have a higher density of $\kappa$ receptors in the cortex relative to other rodent species, ${ }^{10,19,20}$ thus potentially reflecting relatively abundant prodyn expression as well.

\section{Materials and methods}

\section{Tissue preparation}

Six adult male Hartley guinea-pigs weighing between $300-350 \mathrm{~g}$ were sacrificed by rapid decapitation, and their brains were immediately removed and placed on wet ice. The brains were sliced in the coronal plane and punches were taken from ten cortical areas (Table 1) as well as from the caudateputamen $(\mathrm{CPu})$. These punches were stored at $-80^{\circ} \mathrm{C}$ until they were extracted.

\section{Tissue extraction}

Each frozen tissue sample was weighed and extracted simultaneously for peptides and mRNA using a guanidine isothiocyanate $/ \mathrm{LiCl}$ extraction 
Table 1 Cortical regions studied

\begin{tabular}{lll}
\hline $\begin{array}{l}\text { Region } \\
\text { studied }\end{array}$ & $\begin{array}{l}\text { Corresponding } \\
\text { cortical areas }\end{array}$ & $\begin{array}{l}\text { Function } \\
\text { or common name }\end{array}$ \\
\hline $\mathrm{Fr}$ & $\mathrm{Fr} 1, \mathrm{Fr} 2, \mathrm{Fr} 3$ & motor \\
$\mathrm{Ent}$ & $\mathrm{Ent}$ & entorhinal \\
$\mathrm{Te}$ & $\mathrm{Te} 1, \mathrm{Te} 3$ & primary auditory \\
$\mathrm{Cg}$ & $\mathrm{Cg} 1, \mathrm{Cg} 2$ & anterior cingulate (prefrontal) \\
$\mathrm{AI}$ & $\mathrm{AI}, \mathrm{Te} 2$ & insular cortex/auditory association \\
$\mathrm{Par} 1$ & $\mathrm{Par} 1, \mathrm{FL}, \mathrm{HL}$ & primary somatosensory \\
$\mathrm{Par} 2$ & $\mathrm{Par} 2$ & secondary somatosensory \\
$\mathrm{Pir}$ & $\mathrm{Pir}$ & piriform \\
RSG & $\mathrm{RSA}, \mathrm{RSG}$ & retrosplenial (posterior cingulate) \\
$\mathrm{OC}$ & $\mathrm{Oc} 1, \mathrm{Oc} 2 \mathrm{~L}, \mathrm{Oc} 2 \mathrm{M}$ & visual \\
\hline
\end{tabular}

* Corresponding areas are approximate cytoarchitecyural regions contained in each punch using the descriptive nomenclature of Zilles. ${ }^{23}$

procedure. ${ }^{21}$ The supernatant from the initial precipitation (peptide phase) was acidified with acetic acid, and applied to Sep Pak $\mathrm{C}_{18}$ cartridges, washed with $0.1 \%$ trifluoroacetic acid (TFA), and eluted with $60 \%$ acetonitrile in $0.1 \%$ TFA. The eluant was dried by rotary evaporation, and the pellet was resuspended in methanol: $0.1 \mathrm{~N} \mathrm{HCl}(50: 50, \mathrm{v}: \mathrm{v})$ for radioimmunoassay. The $\mathrm{mRNA}$ fraction was purified and ethanol-precipitated, and resuspended in water for Northern analysis.

\section{Peptide assays}

Previously standardized radioimmunoassays ${ }^{16,22}$ were performed on the peptide extracts using antibodies specific for the opioid-active peptides dyn $\mathrm{A}$ (1-17), dyn A (1-8), dyn B, and $\alpha-N E$, using ${ }^{125} I-$ labeled tracers. The dyn $A(1-17)$ antiserum is directed against the $\mathrm{C}$-terminus of this peptide. The $\mathrm{IC}_{50}$ of this assay is approximately $10 \mathrm{fmol} /$ tube. This antiserum has less than $0.001 \%$ cross-reactivity with dyn A (1-8), leucine-enkephalin, or $\alpha-N E$. The dyn $A(1-8)$ antiserum is directed against the C-terminal region of this molecule, and the $\mathrm{IC}_{50}$ of this assay is approximately $6 \mathrm{fmol} /$ tube. This antiserum has less than $0.001 \%$ cross-reactivity with dyn A (1-17), dyn $B$ or leucine-enkephalin, and less than $0.01 \%$ cross-reactivity with $\alpha-\mathrm{NE}$. The dyn B antiserum is approximately $0.002 \%$ cross-reactive with dyn A (1-8), less than $0.001 \%$ cross-reactive with dyn $\mathrm{A}$ $(1-17)$ or $\alpha-\mathrm{NE}$, and has an $\mathrm{IC}_{50}$ of approximately $15 \mathrm{fmol} /$ tube. The $\alpha-\mathrm{NE}$ antiserum is C-terminus directed, has less than $0.001 \%$ cross-reactivity with dyn A (1-8), dyn A (1-17), dyn B, and leucineenkephalin, and has an $\mathrm{IC}_{50}$ of $80 \mathrm{fmol} /$ tube. Each sample was assayed in triplicate, and the means from three different assays were used for subsequent data analysis.

\section{Northern analysis}

RNA samples were chromatographed overnight on $1 \%$ agarose $/ 5 \%$ formamide gels; $5 \mu \mathrm{g}$ of total RNA from each region was loaded on the gels. The next day, RNA bands were transferred to Nytran membranes by blotting. The membranes were subsequently probed with a $\left[{ }^{32} \mathrm{P}\right]$-labelled 733 base riboprobe to rat prodyn. The membranes were then briefly shaken in $0.1 \times \mathrm{SSC}(300 \mathrm{mM} \mathrm{NaCl}, 30 \mathrm{mM}$ sodium citrate, $\mathrm{pH} 7.2$ ), $0.1 \% \mathrm{NaDodSO}_{4}, 1 \mathrm{mM}$ EDTA, then washed in $1.5 \mathrm{~L}$ of the same solution at $70^{\circ} \mathrm{C}$ for $2 \mathrm{~h}$. The membranes were apposed to Kodak X-OMAT film for several weeks at $-80^{\circ} \mathrm{C}$. Following film development, the resulting bands were analyzed by quantitative densitometry.

\section{Data analysis}

Mean values were obtained for individual peptide concentrations in each brain region. A single value for mRNA (expressed in units of optical density from densitometric analysis) was obtained for each region as well. To estimate the extent of interdomain processing of prodyn, the ratios of $\alpha-N E / d y n A, \alpha-$ $\mathrm{NE} /$ dyn $B$, and dyn $A /$ dyn $B$ were calculated. Total dyn $A$ was calculated as the sum of dyn A (1-17) and dyn $A(1-8)$. The ratio dyn $A(1-17) /$ dyn $A(1-8)$ was also calculated as an estimate of intradomain processing for the dyn A region; as these two peptides have different affinities for the opiate receptors, differences in the processing of the ' $A$ ' domain may be physiologically relevant. All data were analyzed by one-way analysis of variance with post-hoc comparisons by Dunnett's t-test, with $\mathrm{p}<0.05$ used to define significant results.

\section{Results}

\section{Peptide content}

Dyn A (1-17) levels were significantly different across the studied regions (Fig. 2). Levels of this peptide tended to be higher in piriform (Pir), entorhinal (Ent), and primary auditory ( $\mathrm{Te}$ ) cortices than in 

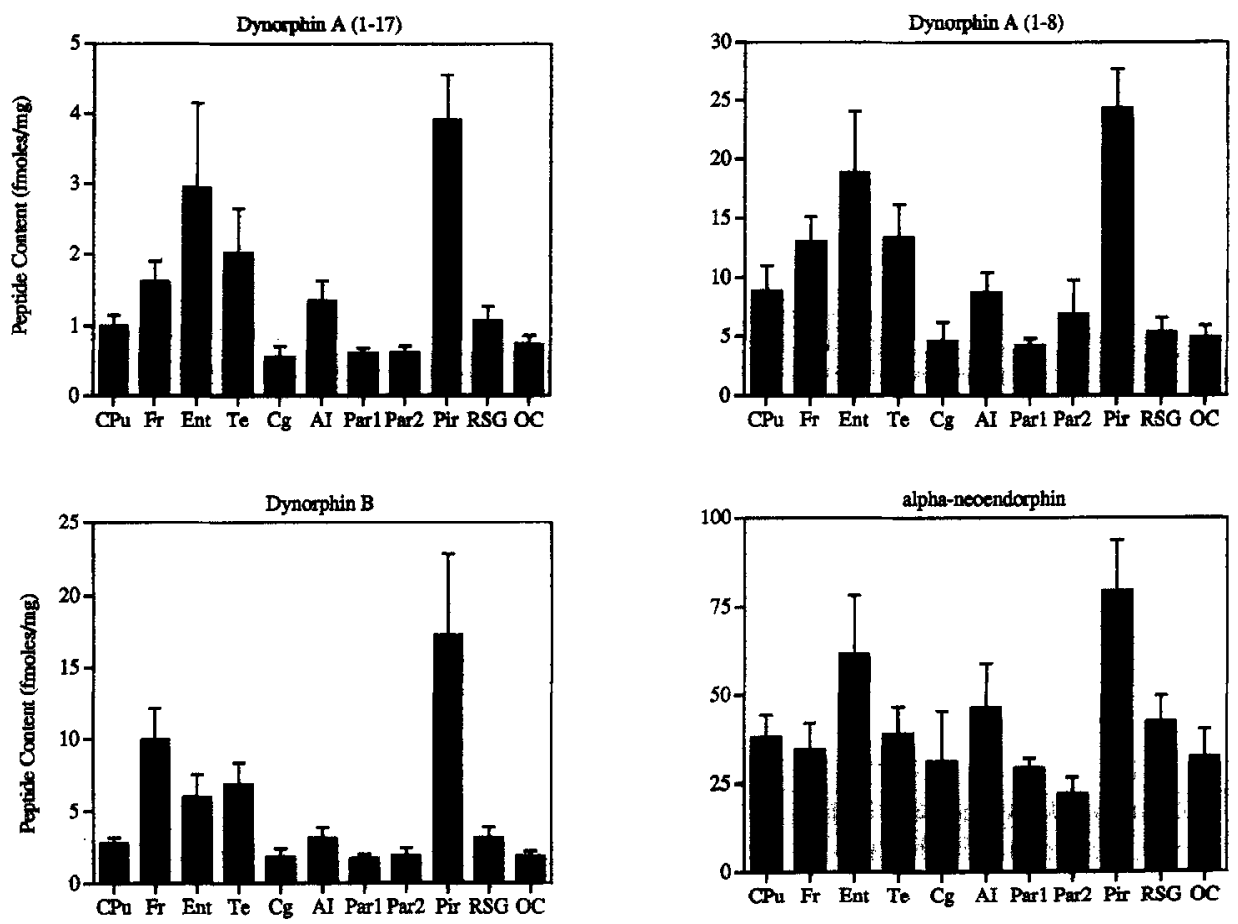

Fig. 2 Concentrations of prodynorphin-derived peptides in cortical regions and in the striatum (CPu). For each of the four peptides, there were significant regional differences in concentration. For dynorphin $A(1-17)$, there were significant differences for region ( $F$ $=4.88, p<0.0001$ ). Significant post-hoc comparisons were: Pir $>$ all other cortical regions, but equal to Ent; Ent $>$ all cortical regions except $\mathrm{Fr}$, Te, and $\mathrm{Pir} ; \mathrm{Te}>\mathrm{Parl}$ and $\mathrm{Cg}$. Only Pir and Ent were significantly different from $\mathrm{CPu}$. For dynorphin $\mathrm{A}(1-8)$ there were also significant regional differences $(F=6.13, p<0.0001)$. Significant post-hoc comparisons were: Pir $>$ all other cortical regions except Ent; Ent > all cortical regions except Pir, Fr, Te; Te > all cortical regions except Ent, Pir, Parl, Cg, RSG; and Fr > Parl, Cg, RSG, OC. As with dynorphin A (1-17), only Pir and Ent were significantly different from CPu. Dynorphin B also exhibited a main effect for region $(F=4.83, p<0.0001)$. Post-hoc comparisons revealed Pir $>$ all other cortical regions; and $\mathrm{Fr}>$ all cortical regions except Ent and Te. Only Pir significantly differed from $\mathrm{CPu}$. Finally, $\alpha$-neoendorphin concentrations differed across regions $(\mathrm{F}=$ $2.13, \mathrm{p}<0.05$ ). Post-hoc comparisons indicated $\mathrm{Pir}>$ all other cortical regions except Ent and Te; and Ent $>\mathrm{Par} 2$. Only Pir $>\mathrm{CPu}$; all other cortical regions were not significantly different from CPu. For abbreviations used, see Table 1.

other cortical regions. Both piriform and entorhinal cortices had significantly higher levels of dyn (A (1-17) than the striatum $(\mathrm{CPu})$, but other cortical regions had levels of this peptide similar to those measured in the striatum.

Dyn A (1-8) had a very similar pattern of distribution to dyn A (1-17), and also showed similar significant differences between cortical regions (Fig. 2). Piriform, entorhinal, and primary auditory cortices tended to be higher than other cortical areas, and the motor area ( $\mathrm{Fr}$ ) had a higher concentration than several other regions. As was found for dyn A (1-17), the levels of dyn A (1-8) in the piriform and entorhinal cortices were significantly elevated over the level found in the striatum.

Dyn $B$ and $\alpha-\mathrm{NE}$ levels also both differed signif- icantly between regions (Fig. 2). The highest levels of dyn B were found in the piriform and motor cortices, and the highest levels of $\alpha-\mathrm{NE}$ in piriform and entorhinal cortices. Of all cortical regions, only the piriform cortex had significantly higher dyn B and $\alpha-N E$ levels than the striatum.

Examination of the relative contribution of each of the four prodyn-derived peptides to the total amount of peptide measured revealed that the greatest contribution in every region studied came from $\alpha-\mathrm{NE}$ (Fig. 3). The next most abundant domain in all regions was dyn $\mathrm{A}$, which was predominantly expressed as dyn A (1-8). Those regions which consistently had the highest individual peptide levels (piriform, entorhinal, primary auditory and motor areas), had the smallest relative contribution from $\alpha-\mathrm{NE}$. 


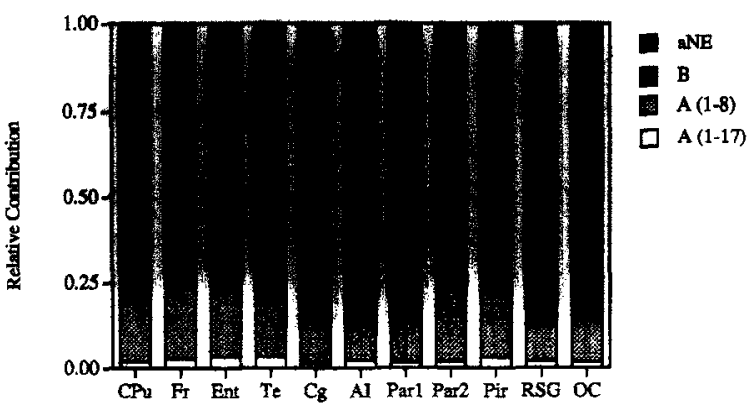

Fig. 3 Relative contribution of each of the four prodynorphinderived peptides to total prodynorphin expression. Note that $\alpha$ neoendorphin is the most abundant form in each region of cortex as well as in the striatum ( $\mathrm{CPu}$ ). The dynorphin $\mathrm{A}$ domain is the next most abundant, comprised in large part of dynorphin A (1-8). In general, the relative contributions of each peptide in the cortical regions is quite similar to what is observed in the striatum.

\section{Peptide processing}

To estimate the extent of the processing of prodyn within different cortical regions, ratios of peptide concentrations were calculated for each region. Both between-domain processing (Fig. 4) and withindomain processing (of the 'A' domain, Fig. 5) comparisons were made.

The ratio $\alpha-\mathrm{NE} / \mathrm{dyn} \mathrm{B}$ was uniformly greater than one, and ranged from 5-18 (Fig. 4). There were significant regional differences in this ratio. In general, this ratio was significantly lower in primary auditory, piriform and motor cortices than in other cortical regions. This ratio was significantly lower in piriform and motor cortex than in the striatum, but did not differ from the striatum in other cortical regions. The ratio $\alpha-\mathrm{NE} / \mathrm{dyn} \mathrm{A}$ was significantly different across regions as well, with higher values in primary somatosensory (Par 1), visual (OC), and retrosplenial (RSG) cortices than in other cortical regions. All cortical regions had a similar value of this ratio compared to the striatum, except for primary somatosensory and retrosplenial cortices, in which this ratio was higher than in the striatum. The ratio dyn A/dyn B was not significantly different between the cortical regions or the striatum.

Within-domain processing was estimated for the ' $A$ ' domain of prodyn (Fig. 5), by determining the ratio of dyn $A(1-17) /$ dyn $A(1-8)$. No significant differences were found either between cortical regions or between any region and the striatum.

\section{Messenger RNA levels}

To examine the possible effects of transcription on the regional variation observed in peptide concentrations and processing, mRNA levels were determined in the same regions. As shown in
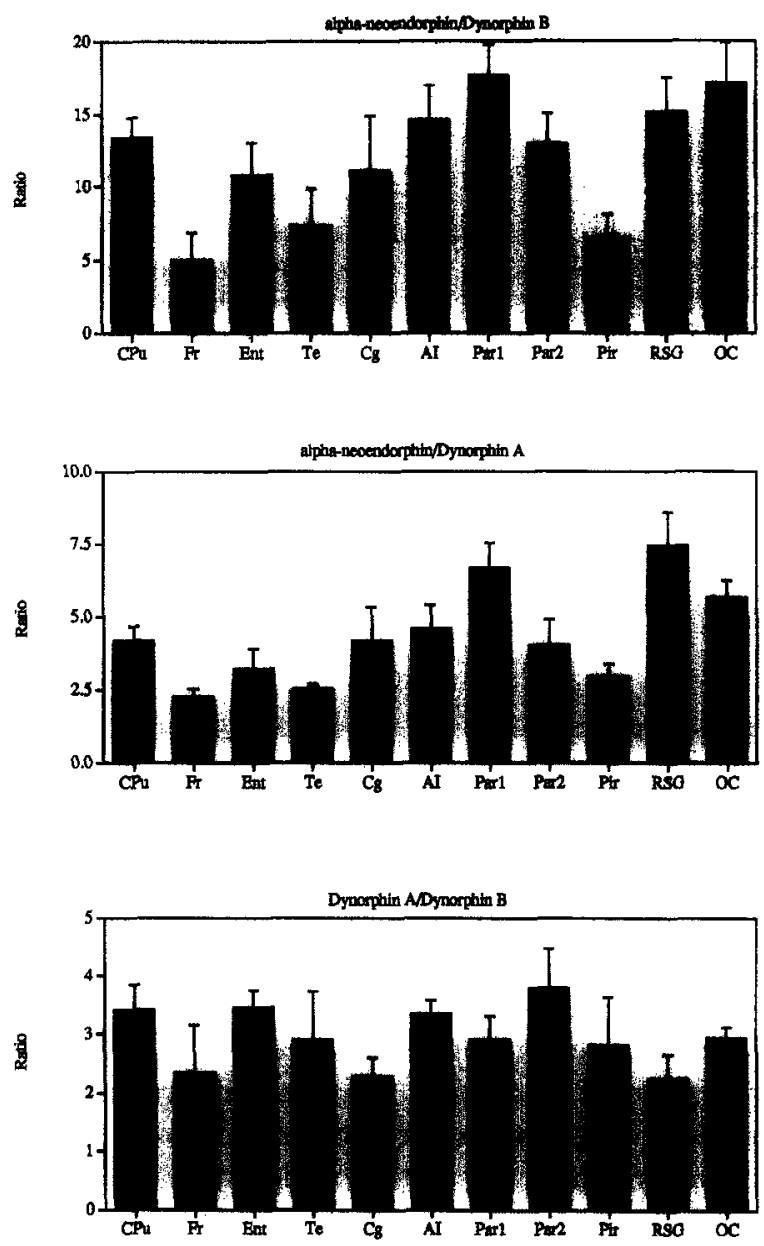

Fig. 4 Between-domain processing of prodynorphin. The ratios of each domain to each of the other two are demonstrated as an estimate of the extent of between-domain processing of prodynorphin. Regional differences were found for the ratio $\alpha$-neoendorphin/dynorphin $B(F=3.30, p<0.005)$. Significant post-hoc comparisons included: Te, Pir, and $\mathrm{Fr}<\mathrm{Par} 1, \mathrm{RSG}, \mathrm{OC}$, and $\mathrm{AI}$; and $\mathrm{Fr}<\mathrm{Par}$. The $\mathrm{CPu}$ was only significantly different from $\mathrm{Fr}$ and $\mathrm{Pir}$, and similar to all other cortical regions. Similarly, the ratio of $\alpha$-neoendorphin/dynorphin A was significantly different across regions $(F=4.97, p<0.0001)$. Significant post-hoc comparisons included: Par1, RSG, OC > Fr, Ent, Te, Pir; Par1 > Par2 and Cg; and RSG $>$ AI $>$ Fr. Only Par1 and RSG were significantly different from $\mathrm{CPu}$. Although there were significant regional differences in the ratios containing $\alpha$-neoendorphin, the ratio of dynorphin $A /$ dynorphin $B$ was not significantly different $(F=0.71)$ across regions. Note that these ratios in cortex are very similar to those in the striatum (CPu) in each case. 


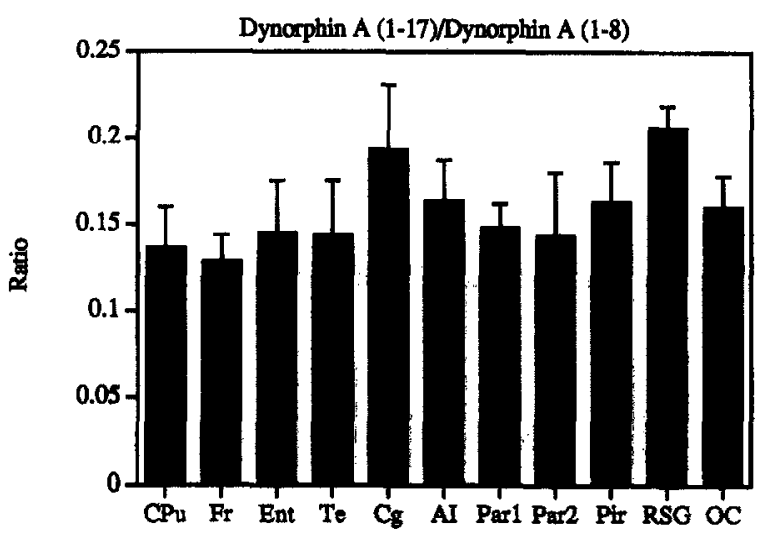

Fig. 5 Ratio of dynorphin A (1-17)/dynorphin A (1-8). This ratio is presented as an estimate of within-domain processing for the ' $A$ ' domain. This ratio was not significantly different $(F=$ 0.67 ) between cortical regions nor from that seen in the striatum.

Table 2, there were no statistically significant differences between cortical regions or between any region and the striatum $(\mathrm{F}=1.33, \mathrm{p}=$ n.s. $)$.

\section{Discussion}

This study was designed to examine prodyn expression and processing in the cortex of the guinea-pig, and to compare these findings with those seen in the more well-understood striatum. For the most part, the cortex and the striatum appear to handle prodyn in a similar manner, at the levels of mRNA expression, peptide content, and apparent extent of posttranslational processing. Some regional variation in peptide levels and extent of processing were found, however, with a few cortical regions having consis-

Table 2 Prodynorphin mRNA content in ten cortical regions and in the striatum

\begin{tabular}{lr}
\hline Region & $m R N A$ \\
\hline CPu & $265 \pm 10$ \\
Fr & $183 \pm 30$ \\
Ent & $276 \pm 28$ \\
Te & $204 \pm 13$ \\
Cg & $169 \pm 42$ \\
AI & $262 \pm 32$ \\
Pir & $170 \pm 84$ \\
RSG & $262 \pm 37$ \\
OC & $96 \pm 55$ \\
\hline
\end{tabular}

Values are expressed as mean \pm SEM in units of optical density. There were no significant differences between the individual regions. tently higher peptide levels, and several regions having relatively less contribution to total peptide levels from $\alpha-N E$, than other cortical regions and the striatum.

As has been previously demonstrated in the rodent nigrostriatal system, ${ }^{16}$ levels of $\alpha-N E$ were considerably higher than levels of any of the products derived from the A \& B domains of prodyn in all regions studied. The structure of prodyn suggests that the three domains might be expected to be present in equal concentrations, yet $\alpha-\mathrm{NE}$ was consistently higher. Trujillo et al $^{16}$ suggested that this phenomenon might be due to the primary amino acid sequence of the prodyn molecule. Each functional domain contains leucine enkephalin as a theoretical product. In both the dyn A \& B domains, the cleavage site for the liberation of enkephalin is the dibasic amino acid pair, arginine-arginine. In the neoendorphin domain, however, this cleavage site is arginine-lysine. The discrepancy in content that has been previously reported and observed in this study may reflect the differential preference of endogenous processing enzymes for these dibasic cleavage sites. This would suggest that argininearginine is more favored for enzyme action than arginine-lysine; accordingly, the prodyn A \& B domains may be further processed to leucine enkephalin, while the neoendorphin domain may not be favored for continued processing to enkephalin. This scenario would result in an apparent accumulation of neoendorphin products relative to longer peptide fragments derivied from the A \& B domains. Whatever the mechanism, however, it appears that the cortex processes the dynorphin precursor in a manner similar to the striatum.

After $\alpha-\mathrm{NE}$, the most abundant domain was dyn A. Dyn A exists as dyn A (1-17), or can be further processed to dyn A (1-8). Dyn A (1-8) was found in higher concentrations than dyn A (1-17), which suggests a relatively greater $\delta$ versus $\kappa$ opioid tone associated with the A domain in the cortex. Further, the cortex appears to process the A domain much like the striatum.

Despite the similarity of prodyn expression within the cortex and between cortical regions and the striatum, there were several significant differences. Four regions of cortex (piriform, entorhinal, primary auditory and motor areas), tended to have higher peptide levels than other regions. Of these 
four areas, the piriform and entorhinal were the highest, and were the only areas to consistently have levels significantly higher than the striatum. Both the piriform and entorhinal regions are associated with limbic integration functions, and this consistent elevation of peptide levels may be associated with this functional role of these regions. It is not clear, however, why primary auditory and motor areas might also have increased peptide levels; these differences will need to be the subject of future investigation.

In comparing peptide ratios to explore possible differences in apparent peptide processing, there was again similarity seen between the cortex and striatum. While the $\alpha-N E / d y n A$ and $\alpha-N E / d y n$ B ratios showed some variability, the dyn $A / d y n B$, and dyn $A(1-17) /$ dyn $A(1-8)$ were remarkably similar throughout cortex and striatum. Processing differences appeared to be related to the extent of expression of the neoendorphin domain: in those regions with the highest total peptide levels, the relative contribution from $\alpha-\mathrm{NE}$ was the lowest, hence the ratios containing $\alpha-N E$ were lower in those specific regions. One possible explanation for this is that processing enzymes that convert dyn $\mathrm{A}$ and dyn $\mathrm{B}$ into leucine enkephalin may be substrate saturated or otherwise less active in those regions of cortex with higher total dyn content.

To determine at what level of prodyn gene regulation the observed content and processing differences might occur, prodyn mRNA levels were also determined in the same regions. There were no significant differences in prodyn mRNA between cortical regions or between the cortex and the striatum. These data suggest that the variability found in peptide expression is not transcriptionally mediated, but is rather determined at the level of translation or post-translational processing.

These results indicate that with the exception of a few cortical areas, prodyn is handled quite similarly in the cortex and the striatum of the guinea-pig. There were a few regional differences found, with increased peptide levels being present in limbic, auditory, and motor cortical regions, but the significance of this remains unclear. In general, however, it appears that dynorphin may serve a general rather than a region-specific function throughout much of the cortex.

\section{Acknowledgements}

The authors would like to acknowledge the generous gift of antisera used in this study which was provided by Dr Huda Akil, as well as to thank her for her guidance, training, and encouragement. Dr Meador-Woodruff was supported by a Research Scientist Development Award from the National Institute of Mental Health (K01 MH00818). Mr Ramsdell was the recipient of a Student Biomedical Research Fellowship from the University of Michigan Medical School (T35 HL07690).

\section{References}

1. Akil, H., Bronstein, D. and Mansour, A. (1988). Overview of the endogenous opioid systems: anatomical, biochemical and functional issues. In: Rodgers, R. J. and Cooper, S. J. (eds) Endorphins, Opiates and Behavioural Processes. John Wiley and Sons, p 1-23.

2. Garzon, J., Sanchez-Blazquez, P., Hollt, V., Lee, N. M. and Loh, H. H. (1983). Endogenous opioid peptides: Comparative evaluation of their receptor affinities in the mouse brain. Life Sci. 33: 291-294.

3. Leslie, F. M. (1987). Methods used for the study of opioid receptors. Pharmacol. Rev. 39: 197-249.

4. Akil, H., Hewlett, W., Barchas, J. D. and Li, C. H. (1980). Binding of $\left[{ }^{3} \mathrm{H}\right] \beta$-endorphin to rat brain membranes: Characterization and opiate properties. Eur. J. Pharmacol. 64: $1-8$

5. Fallon, J. H. and Leslie, F. M. (1986). Distribution of dynorphin and enkephalin peptides in the rat brain. J. Comp. Neurol. 249: 293-336.

6. Geary, W. A. and Wooten, G. F. (1983). Quantitative film autoradiography of opiate agonist and antagonist binding in rat brain. J. Pharmacol. Exp. Ther. 225: 234-240.

7. Khachaturian, H., Lewis, M. E., Haber, S. N., Houghten, R. A., Akil, H. and Watson, S. J. (1985). Prodynorphin peptide immunocytochemistry in rhesus monkey brain. Peptides 6 (Suppl. 2): 155-166.

8. Lewis, M. E., Khachaturian, H. and Watson, S. J. (1983). Comparative distribution of opiate receptors and three opioid peptide neuronal systems in rhesus monkey central nervous system. Life Sci. 33: 239-242.

9. Lewis, M. E., Pert, A., Pert, C. B. and Herkenham, M. (1983). Opiate receptor localization in rat cerebral cortex. J. Comp. Neurol. 216: 339-358.

10. McLean, S., Rothman, R. B., Jacobson, A. E., Rice, K. C. and Herkenham, M. (1987). Distribution of opiate receptor subtypes and enkephalin and dynorphin immunoreactivity in the hippocampus of squirrel, guinea-pig, rat, and hamster. J. Comp. Neurol. 255: 497-510.

11. Slater, P. and Cross, A. J. (1980). Autoradiographic distribution of dynorphin 1-9 binding sites in primate brain. Neuropeptides 8: 71-76.

12. Suda, T., Tozawa, F., Tachibana, S., Demura, H. and Shizume, K. (1982). Multiple forms of immunoreactive dynorphin in rat pituitary and brain. Life Sci. 31: 51-57.

13. Tempei, A. and Zukin, R. S. (1987). Neuroanatomical patterns of the $\mu, \delta$ and $\kappa$ opioid receptors of rat brain as determined by quantitative in vitro autoradiography. Proc. Natl. Acad. Sci. USA 84: 4308-4312.

14. Fallon, J. H., Leslie, F. M. and Cone, R. I. (1985). Dynorphincontaining pathways in the substantia nigra and ventral tegmentum: a double labeling study using combined immunofluorescence and retrograde tracing. Neuropeptides 5: $457-460$. 
15. McLean, S., Bannon, M. J., Zamir, N. and Pert, C. B. (1985). Comparison of the substance P- and dynorphincontaining projections to the substantia nigra: a radioimmunocytochemical and biochemical study. Brain Res. 361 : 185-192.

16. Trujillo, K. A., Day, R. and Akil, H. (1990). Regulation of striatonigral prodynorphin peptides by dopaminergic agents. Brain Res. 518: 244-256.

17. Taquet, H., Javoy-Agid, F., Mauborgne, A. et al. (1988), Biochemical mapping of cholecystokinin-, substance P-, [met]enkephalin, [leu]enkephalin- and dynorphin A (1-8)like immunoreactivities in the human cerebral cortex. Neuroscience 27: 871-883.

18. Sato, M., Morita, Y., Saika, T., Fujita, M., Ohhata, K. and Tohyama, M. (1991). Localization and ontogeny of cells expressing preprodynorphin mRNA in the rat cerebral cor- tex. Brain Res. 541: 41-49.

19. Foote, R. W. and Maurer, R. (1986). Distribution of opioid binding sites in the guinea-pig hippocampus as compared to the rat: A quantitative analysis. Neuroscience 19: 847-856.

20. Mansour, A., Khachaturian, H., Lewis, M. E., Akil, H. and Watson, S. J. (1988). Anatomy of CNS opioid receptors. Trends Neurosci. 11: 308-314.

21. Cathala, G., Savouret, J. T., Mendez, B., West, B. L., Karin, M., Martial, J. A. and Bexter, J. D. (1983). A method for the isolation of intact, translationally active ribonucleic acid. DNA 2: 329-335.

22. Day, R and Akil, H. (1989). The post-translational processing of prodynorphin in the rat anterior pituitary. Endocrinology 124: 2392-2405.

23. Zilles, K. (1985). The cortex of the rat: A stereotaxic atlas. Springer-Verlag, Berlin. 